\title{
Nanoparticles-Based Oligonucleotides Delivery in Cancer: Role of Zebrafish as Animal Model
}

\author{
Sara Bozzer $^{1} \mathbb{D}$, Michele Dal Bo ${ }^{2} \mathbb{D}$, Giuseppe Toffoli ${ }^{2} \mathbb{D}$, Paolo Macor $^{1, * \mathbb{D}}$ and Sara Capolla ${ }^{2} \mathbb{D}$ \\ 1 Department of Life Sciences, University of Trieste, 34127 Trieste, Italy; sara.bozzer@phd.units.it \\ 2 Experimental and Clinical Pharmacology Unit, Centro di Riferimento Oncologico di Aviano (CRO), IRCCS, \\ 33081 Aviano, Italy; mdalbo@cro.it (M.D.B.); gtoffoli@cro.it (G.T.); sara.capolla@cro.it (S.C.) \\ * Correspondence: pmacor@units.it
}

Citation: Bozzer, S.; Bo, M.D.;

Toffoli, G.; Macor, P.; Capolla, S.

Nanoparticles-Based

Oligonucleotides Delivery in Cancer: Role of Zebrafish as Animal Model.

Pharmaceutics 2021, 13, 1106.

https://doi.org/10.3390/

pharmaceutics 13081106

Academic Editor: Anna Scomparin

Received: 29 June 2021

Accepted: 18 July 2021

Published: 21 July 2021

Publisher's Note: MDPI stays neutral with regard to jurisdictional claims in published maps and institutional affiliations.

Copyright: (C) 2021 by the authors Licensee MDPI, Basel, Switzerland This article is an open access article distributed under the terms and conditions of the Creative Commons Attribution (CC BY) license (https:// creativecommons.org/licenses/by/ $4.0 /)$

\begin{abstract}
Oligonucleotide (ON) therapeutics are molecular target agents composed of chemically synthesized DNA or RNA molecules capable of inhibiting gene expression or protein function. How ON therapeutics can efficiently reach the inside of target cells remains a problem still to be solved in the majority of potential clinical applications. The chemical structure of ON compounds could affect their capability to pass through the plasma membrane. Other key factors are nuclease degradation in the extracellular space, renal clearance, reticulo-endothelial system, and at the target cell level, the endolysosomal system and the possible export via exocytosis. Several delivery platforms have been proposed to overcome these limits including the use of lipidic, polymeric, and inorganic nanoparticles, or hybrids between them. The possibility of evaluating the efficacy of the proposed therapeutic strategies in useful in vivo models is still a pivotal need, and the employment of zebrafish (ZF) models could expand the range of possibilities. In this review, we briefly describe the main ON therapeutics proposed for anticancer treatment, and the different strategies employed for their delivery to cancer cells. The principal features of ZF models and the pros and cons of their employment in the development of ON-based therapeutic strategies are also discussed.
\end{abstract}

Keywords: oligonucleotides; nanoparticles; zebrafish

\section{Introduction}

In recent years, molecular target agents, constituted by chemically synthesized antisense oligonucleotides (ASOs), small interfering RNA (siRNA), microRNA (miRNA), aptamers, and decoys, have been proposed as interesting therapeutic compounds for anticancer treatments [1]. They are based on chemically synthesized oligonucleotides (ONs) with a single- or double-stranded deoxyribonucleic acid (DNA) or ribonucleic acid (RNA) chain with a specific molecular target. This target can be represented by a specific gene, protein, or a class/family of genes or proteins [2]. In this context, the various molecular profiling strategies that have recently been introduced in the cancer field of studies have dramatically increased the range of molecular targets [3]. The capability to be highly specific for a particular molecular target can be of great interest in the case of anticancer therapies in which other conventional or innovative drugs are inefficacious. In the last two decades, diverse advances have been made in the potential application fields of ON technologies with both diagnostic or therapeutic purposes, particularly due to the possibility of acting at different stages of tumor pathogenesis and progression for the different mechanisms of action [4-6]. In particular, ASO, siRNA, and miRNA can act at transcription level by targeting specific messenger RNAs (mRNAs), aptamers are capable of directly inhibiting the activity of proteins whereas decoys are capable of targeting specific DNA coding transcription factors (Table 1) [4-6].

Although a significant number of phase III clinical trials based on ONs have already been proposed, aspects related to their efficacy still limit the introduction of ON-based compounds in clinical practice for anticancer treatment [2]. In particular, further studies 
are needed to understand better drug delivery strategies for each proposed ON-based compound and to develop in vivo models in which the efficacy and the toxicity of these approaches can be evaluated. In this context, the employment of zebrafish (ZF) models could expand the range of possibilities to understand the efficacy of the investigated therapeutic strategies [7].

Table 1. Therapeutic oligonucleotides (ONs). ASO: antisense oligonucleotides; DNA: deoxyribonucleic acid; RNA: ribonucleic acid; ssDNA: single strand DNA; dsDNA: double strand DNA; ssRNA: single strand RNA; dsRNA: double strand RNA; siRNA: small interfering RNA; RISC: RNA induced silencing complex; mRNA: messenger RNA; miRNA: microRNA; antagomiR: anti-miRNA.

\begin{tabular}{|c|c|c|c|c|}
\hline ONs & $\begin{array}{l}\text { Nucleic Acid } \\
\text { Composition }\end{array}$ & $\begin{array}{c}\text { Lenght } \\
\text { (Nucleotides) }\end{array}$ & Mechanisms of Action & Effects \\
\hline \multirow{2}{*}{ ASO } & \multirow{2}{*}{ ssDNA or ssRNA } & \multirow{2}{*}{$18-30$} & $\begin{array}{l}\text { Formation of RNA-DNA duplex } \\
\text { recognized by RNASEH1 }\end{array}$ & $\begin{array}{l}\text { Silencing of gene expression } \\
\text { after RNA degradation }\end{array}$ \\
\hline & & & Steric block & $\begin{array}{l}\text { Modulation of alternative } \\
\text { splicing or translation block }\end{array}$ \\
\hline siRNA & dsRNA & 21 & $\begin{array}{l}\text { RISC is guided } \\
\text { to the complementary } \\
\text { target transcripts }\end{array}$ & $\begin{array}{l}\text { Degradation of the target } \\
\text { mRNA, gene silencing }\end{array}$ \\
\hline miRNA mimics & dsRNA & $\sim 20$ & $\begin{array}{l}\text { Increased level of a } \\
\text { specific miRNA }\end{array}$ & Restore of miRNAs level \\
\hline antagomiR & ssRNA & $\sim 20$ & Direct binding to RISC & $\begin{array}{l}\text { Translation repression or } \\
\text { miRNA degradation }\end{array}$ \\
\hline Aptamers & ssDNA or ssRNA & $20-100$ & Mimic of the promoter sequence & Block of protein translation \\
\hline Decoys & dsDNA or dsRNA & $15-20$ & $\begin{array}{l}\text { Mimic binding site of } \\
\text { transcription factors }\end{array}$ & Transcription silencing \\
\hline
\end{tabular}

In the present review, we summarize the main ON therapeutics that have been proposed for anticancer treatments. We also describe the different structures employed for the delivery of these ON compounds to the cancer cells as well as the principal features of ZF models and the pros and cons of their employment as in vivo models in the development of ON-based therapeutic strategies.

\section{ON Therapeutics}

\subsection{Antisense Oligonucleotides (ASOs)}

ASOs are synthetic, single-stranded nucleic acid polymers of various chemistries with a size of about 18-30 nucleotides. Depending on their mechanisms of action, they can be divided into two different groups, that is, RNase competent and steric block.

In the case of RNase competent, the degradation of RNA is catalyzed by the RNase H enzyme RNASEH1 in presence of the RNA-DNA duplex formed by the binding of the DNA-based ONs with their specific mRNA transcripts. Thus, the target gene expression is silenced (Figure 1A) [8,9]. A central DNA-based "gap" surrounded by flanking regions, constituted by chemically modified RNA promoting target binding, constitutes the recently proposed RNase H-competent ASOs [10]. Being RNASEH1 active in both the cytoplasm and the nucleus, this technology enables the targeting of nuclear transcripts-in particular for immature pre-mRNAs and long non-coding RNAs-while for other technologies, such as siRNA, the silencing in the nucleus context is more difficult $[11,12]$. 
(A) RNase competent ASOs

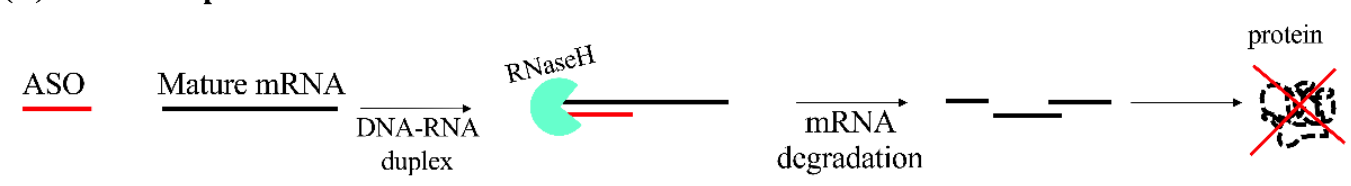

(B) Steric block ASOs
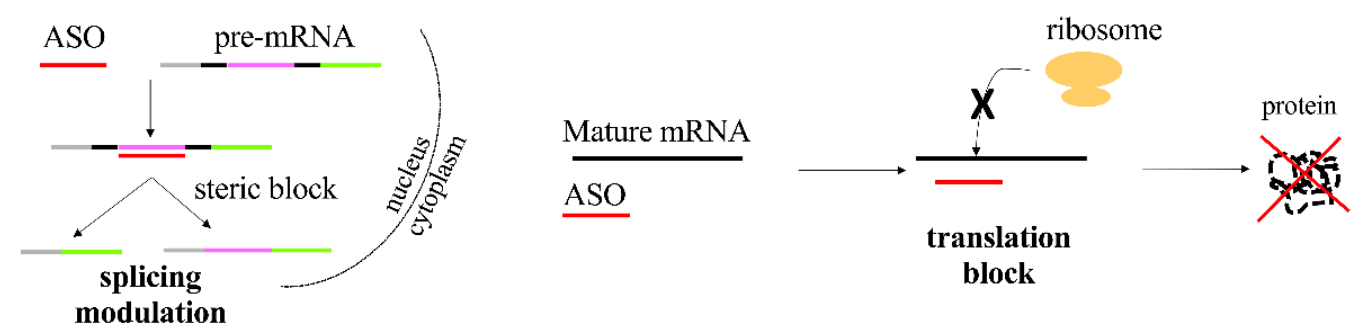

Figure 1. Therapeutic ASOs. Schematic representation of the mechanism of action of antisense oligonucleotides (ASOs) (A) RNase competent and (B) steric block. mRNA: messenger RNA.

Steric block ONs represent the second group of ASOs. They can interfere with either transcript RNA-RNA, RNA-protein, or both, interactions by masking specific sequences within a target transcript. The modulation of alternative splicing to selectively choose a specific transcript by excluding or retaining specific exon(s) is so far one of the most employed applications of this technology. This results in the alteration of splicing because of the masking of a splicing signal inhibiting the spliceosome function (Figure 1B).

The described approach has been suggested for rescuing of the production of a protein with a therapeutic functionality $[13,14]$. Moreover, the same approach has been also used to disrupt the translation of a specific target gene. Splicing modulation, achieved through this approach, can also make it possible to select the preferred isoform for a selected protein $[15,16]$. Steric block ONs can also be employed for the neutralization of translation inhibition interfering with upstream open reading frames that negatively regulate translation [17-19].

\section{2. $\operatorname{siRNA}$}

It is possible to cause the inhibition of RNA using siRNA molecules. They are constituted by a duplex of two RNA molecules of 21 nucleotides where 19 complementary bases and two $3^{\prime}$ overhangs of 2 nucleotides are present [20]. The siRNA is the guide or antisense strand that is complementary to the target transcript, while the other strand is the passenger or sense strand. siRNA molecule activity is carried out guiding the Argonaute2 protein (AGO2) in the context of the RNA-induced silencing complex (RISC) to the complementary target transcripts. siRNA and target transcript complete complementarity determines the cleavage of the target opposite position of the guide strand catalyzed by AGO2, that results in gene silencing (Figure 2) [21-23].

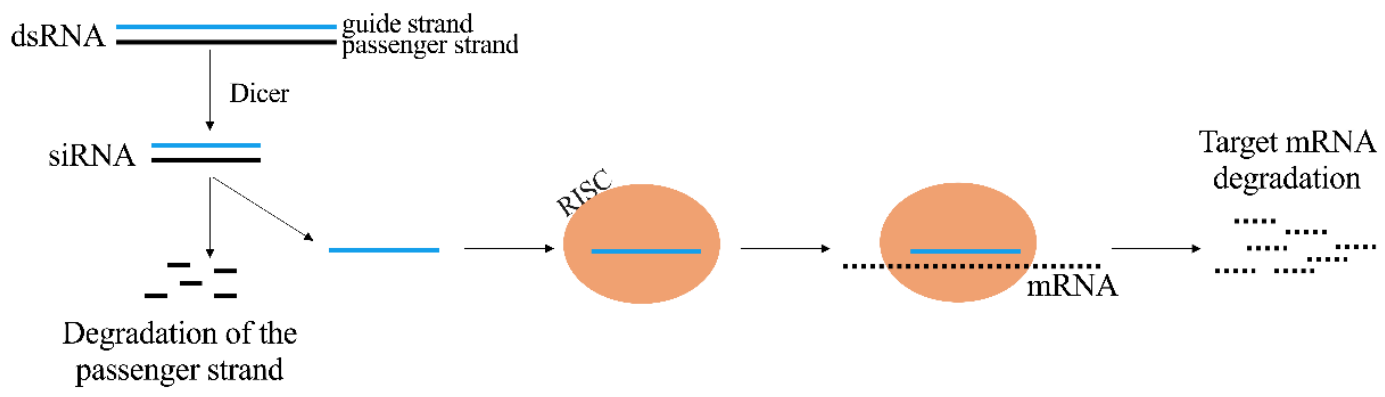

Figure 2. Mechanism of action of therapeutic siRNA. dsRNA: double strand RNA; siRNA: short interference RNA; RISC: RNA-induced silencing complex; mRNA: messenger RNA. 
Several approaches have been introduced to ameliorate the efficacy of siRNA including single stranded siRNAs, divalent siRNAs, Dicer substrate siRNAs, small internally segmented siRNAs, and self-delivering siRNAs [24-29].

\section{3. miRNAs}

The overexpression of miRNAs or their underexpression can be found in various tumor types and disease states. miRNA mimics and anti-miRNAs (antagomiRs) are two approaches developed in order to modulate a specific miRNA level (Figure 3). For the purpose of restoring the lowered expression of endogenous miRNA associated with tumor suppressor functions, miRNA mimics are synthetized as miRNA duplexes whose sequences are the same as the endogenous miRNA. Specific steric block ASOs, termed antagomiRs, are able to effectively silence miRNAs through direct binding within the RISC complex $[30,31]$. Alternatively, miRNAs' regulatory functions can be inhibited by masking the respective target sequence on the mRNA transcript with the use of steric block ASO [31].

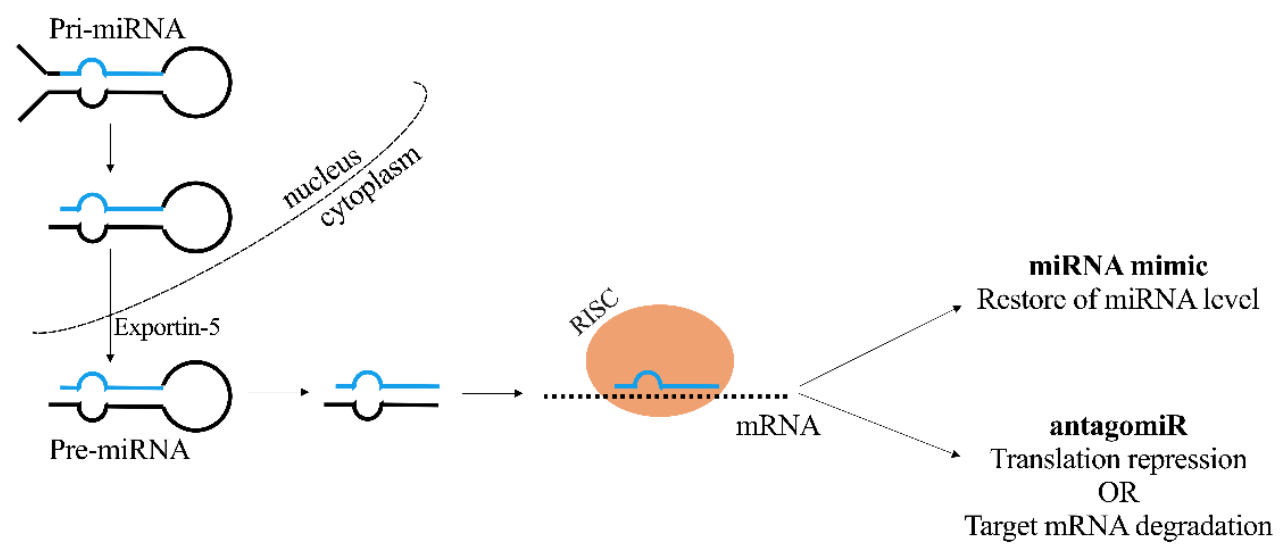

Figure 3. Mechanism of action of therapeutic miRNA. miRNA: microRNA; RISC: RNA-induced silencing complex; antagomiR: anti-miRNA; mRNA: messenger RNA.

\subsection{Aptamers}

About 20-100 nucleotides folding into defined secondary structures comprise the aptamers, consisting of single-stranded nucleic acid molecules. Thanks to their threedimensional structure, aptamers can bind with target proteins (Figure 4).

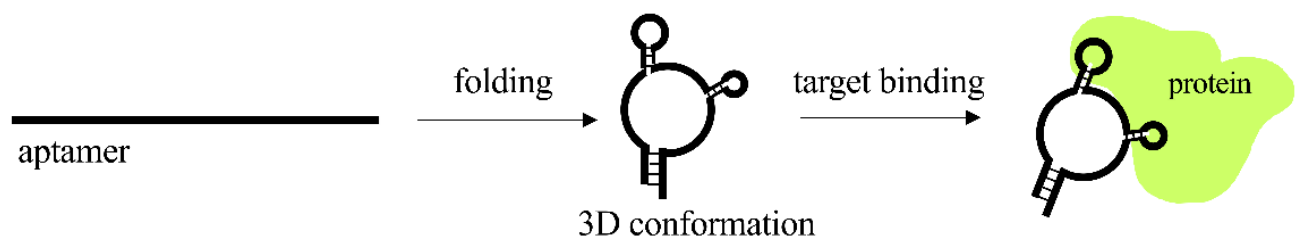

Figure 4. Mechanism of action of aptamers.

Differently from the ONs used for therapeutic purposes for which the therapeutic target can only be intracellular, aptamer therapeutics can be developed for intracellular, extracellular, or cell-surface targets. In particular, for these latter two classes of possible targets, there is no necessity to cross the cell membrane. Thus, in a similar way to monoclonal antibodies, aptamers can be used with therapeutic purposes in any disease for which extracellular blockade of protein-protein interactions is required, including anticancer treatments. In the context of anticancer treatments, aptamers have been proposed for their capability to reach the tumor site in difficult contexts, as in the case of solid tumors or metastasis. Aptamers have also been proposed as delivery tools to enhance anti-tumor immunity by the expression of immunogenic neoantigens [32-34]. The methodology to 
produce aptamers in vitro is called systematic evolution of ligands by exponential enrichment (SELEX) [35-37]. The SELEX methodology can be carried out through the use of libraries of chemically modified RNAs with nucleotide analogues, namely, $2^{\prime}$-fluoro or 2'-O-methyl recognized in the reverse transcriptase and T7 RNA polymerase steps. Alternatively, in order to increase the efficacy of aptamers as therapeutic compounds, chemical modifications can be introduced successively to the SELEX process [38]. Of note, in many cases, a developed aptamer selected to bind to a specific protein is also capable of inhibiting its function. A possible explanation for this is that the protein active sites show more exposed heteroatoms for hydrogen bonding and other interactions. An alternative possibility is that since aptamers can have a limited number of possible interactions with a protein target, they are more likely selected when they fit into a crevice on a protein, such as an active site, according to the so-called homing principle [35-37]. Thus, aptamers generally function as antagonists as they tend to inhibit protein-protein interactions, such as receptor-ligand interactions. However, in some cases, aptamers can act as agonists, as in the case of aptamers isolated against the extracellular domain of the protein human epidermal growth factor receptor 3 (HER3). On the other hand, it has been demonstrated that a DNA aptamer, isolated against an isoleucyl tRNA (RNA transfer) synthetase, is capable of enhancing editing activity. In order to increase target affinity and specificity, as well as the capability to show a long half-life when present in the biological target site, several SELEX methodologies have been proposed. This is particularly important for aptamers with antagonist functions, given that in this case the therapeutic effects can be present as long as the aptamer can physically dock with the target. Thus, the therapeutic effect can be more prolonged in the case of higher binding affinity [33].

\subsection{Decoys}

A double-stranded DNA or RNA structure characterizes decoys, which are able to inhibit the DNA transcription as they block the activity of double stranded-binding transcription factors (Figure 5). Specifically, they are capable of mimicking the specific region of a target transcription factor related to the binding site in the cis-regulatory promoter sequence of a target gene. Even so, the expression of the transcription factor itself cannot always be blocked by these molecules $[39,40]$.

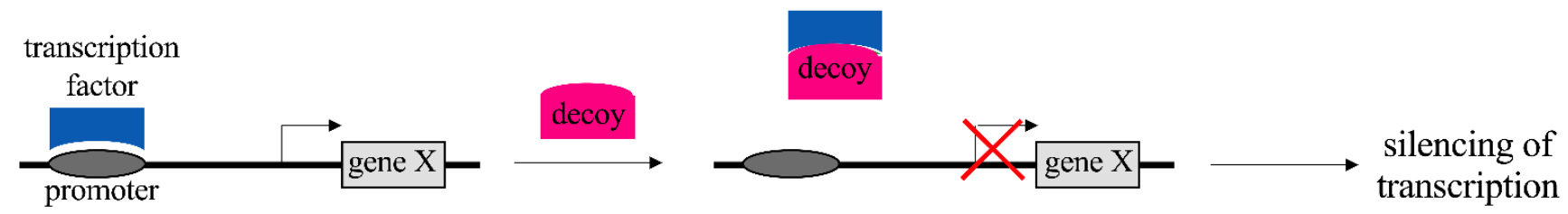

Figure 5. Representation of the mechanism of action of decoys.

\section{Platforms for the Delivery of Oligonucleotides (ONs)}

ONs mainly act within the intracellular space. There are biological barriers that have to be overcome by ONs to reach the target when administered in vivo. In particular, in the case of systemic administration a limit may be represented by the tissue uptake that has to be maximized, whereas the exposure to other tissues not representing the target has to be avoided [41]. Moreover, the cellular uptake of ONs mainly occurs via different types of endocytosis through which ONs subsequently move into the endolysosomal system [42], and traffic into multiple membrane-bound intracellular compartments [43]. There are membrane barriers capable of separating the ONs accumulated by cells from the cytosol and the nucleus, thus determining both effective and non-effective pathways of cellular uptake. In particular, different endocytosis processes have been related in the uptake of ONs [44]. One of them is the coated pit pathway that utilizes adaptor proteins, a clathrin network and the guanosine triphosphate hydrolase (GTPase) dynamin to concentrate ligand-bound receptors at the cell surface and direct them into the cells [45]. 
Moreover, compact structures named caveolae, originating from membrane structures with a high quantity of cholesterol, sphingolipids, and caveolin, have been found to play a role in the internalization of several receptors and ligands [46]. The fluid phase endocytosis is exerted by the cells through the formation of tubular endosomes by the action of the clathrin-independent carrier/GPI-anchored protein-enriched early endosomal compartment (CLIC/GEEC) pathway. Moreover, large amounts of cellular fluid can be pinched off and engulfed by cells through an actinomyosin-driven process called macropinocytosis $[47,48]$. The trafficking through a complex network of endomembrane compartments is the second step of endocytosis. These compartments are represented by early and recycling endosomes, lysosomes, the Golgi apparatus, and the endoplasmic reticulum [49]. As mentioned above, the first step of internalization is made by early endosomes. Then, ONs can be shunted to lysosomes or recycled to the plasma membrane and the cell exterior. In many cases, the early endosome is where the dissociation between receptor and cargo happens [50]. Lysosomes are dense organelles that thanks to the action of hydrolases in a 4.5-5.5 $\mathrm{pH}$ range are the sites in which proteins, lipids, carbohydrates, and nucleic acids are degraded to their primary constituents [51]. Moreover, lysosomes are key actors of the autophagy machinery [52]. The link between early endosomes and lysosomes is not linear and there are several branches and loops, including those involving the Golgi apparatus and the endoplasmic reticulum [53,54]. Only a small fraction of ONs can escape to avoid degradation in the lysosomal environment, thus becoming available at the site of action [55]. In general, single-stranded ONs, being generally either small, uncharged, hydrophobic, or in combination, can be considered to be capable to productively enter cells and escape endosomes through a process called gymnosis [56], without the use of a delivery agent, and for which, however, there is the need of relatively high doses of ONs [43].

On the other hand, the vast majority of ONs are too large and charged to easily enter cells, thus requiring either delivery agents, chemical modifications, or both. These approaches are focused to accelerate the rate of cellular uptake and intracellular trafficking, as well as to facilitate endosomal escape, and can be subdivided into approaches for the direct conjugation to carriers and approaches for the loading in the nanoparticle carriers $[41,55,57]$. To be efficient, delivery systems must overcome the limits observed by the systemic administration of free ONs, ensuring the protection from premature degradation, the delivery to the target tissue, the cellular uptake and also the escape from the lysosomal environment [58]. With these aims, viral and non-viral vectors were produced. Viral carriers are widely used because of their high tolerability, standardized transfection procedures, great high and stable transfection efficiency, and high stability $[59,60]$. Other major features of viral vectors include their ability to infect specific cells through a process known as "tropism" and to transfer ONs in both dividing and non-dividing cells [60]. However, the use of viral vectors is limited by their difficult large-scale production, high production costs and a certain degree of immunogenicity and potential carcinogenicity $[59,60]$. Therefore, efforts were concentrated on the development of specific, safe and easy-to-fabricate non-viral vectors. Among them, remarkable carriers for the delivery of ONs are represented by lipidic, polymeric, and inorganic nanoparticles (NPs), also combined with each other (hybrids).

\subsection{Lipid Nanoparticles}

Lipid nanoparticles (LNPs) gained much attention in the 1980s when Felgner and colleagues demonstrated that the association of plasmid DNA (pDNA) with cationic lipids such as 1,2-di-O-octade-cenyl-3-trimethylammonium propane (DOTMA) and dioleyl phosphatidylethanolamine (DOPE) induced the in vitro and, lately, the in vivo transfection of cells [61]. All the subsequent studies on LNPs culminated in 2018 with the US Food and Drug Administration (FDA) approval of Patisiran (ONPATTRO) as a carrier for siRNA delivery into cells for the treatment of hereditary transthyretin (hATTR) amyloidosis [62]. Due to successful results in preclinical and clinical studies, LNPs are currently the only 
structures approved by the FDA as drug delivery carriers. As a matter of fact, by now, there are eight FDA- and European Medicine Association (EMA)-approved LNPs, but none of them are used for the delivery of ONs. In the way, a variety of RNA-LNPs have recently entered clinical trials and 7 out of 13 have been proposed for tumor treatment [63]. LNPs are classified into 5 different categories on the basis of their synthesis method and physicochemical properties: liposomes, niosomes, transfersomes, solid lipid nanoparticles (SLNPs), and nanostructured lipid carriers (NLCs) [63]. Liposomes represent the traditional type of LNPs and are composed of phospholipids and cholesterol. They constitute the most part- 5 out of 8-of FDA/EMA-approved LNPs. Together with liposomes, niosomes and transfersomes are also lipophilic bi/multi-layer NPs. This particular structure allows the encapsulation of hydrophobic and hydrophilic drugs, which are preferentially incorporated in the external bilayer and the aqueous inner core, respectively. Despite their advantages such as the protection of the cargo, the sustainable drug release, and improved bioavailability, they suffer from some limitations such as toxicity, low loading ability, and their limited stability. SLNPs lack an aqueous core improving the loading efficiency of hydrophobic drugs in respect to liposomes. Furthermore, their rigid core increases their stability. NLCs have an imperfect crystal interior formed by a mixture of solid and liquid lipids which dramatically increases drug loading, also inhibiting drug release during storage [63].

In their modern definition, LNPs have a dimension of less than $1 \mu \mathrm{m}$ and contain phospholipids, lipid anchored polyethylene glycol (PEG), cholesterol, and cationic/ionizable amino lipids (Figure 6A).

(A) LNPs

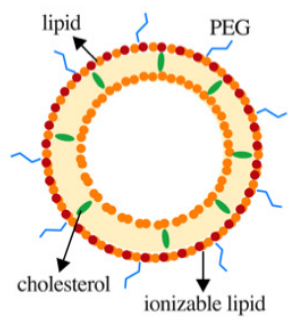

(D) Exosomes

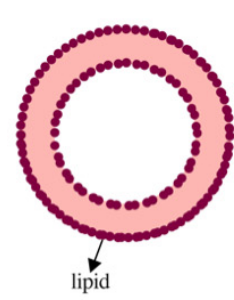

(B) Polymeric NPs

PROS

High positive charge

High loading ability

CONS

Toxicity

Immune system activation

ONs loaded

ASOs, miRNA, siRNA

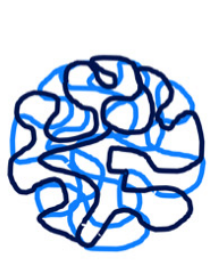

PROS

High stability

Tunable surface

CONS

Low trasfection efficiency (chitosan)

In vivo toxicity (PEI)

ONs loaded

miRNA, siRNA
(C) AuNPs

\section{PROS}

Tunable size and surface

Chemical and thermal stability

Low toxicity

CONS

Low trasfection efficiency

ONs loaded

miRNA, siRNA, decoys

Figure 6. Schematic representation of different types of NPs for ONs delivery. Pros and cons of different types of nanoparticles (NPs) used for oligonucleotides (ONs) delivery: (A) lipid nanoparticles (LNPs), (B) polymeric NPs, (C) gold NPs (AuNPs), (D) exosomes and (E) hybrids. PEG: polyethylene glycol; ASOs: antisense oligonucleotides; miRNAs: microRNAs; siRNAs: small interfering RNAs; PEI: polyethyleneimine.

PEG and cholesterol are known to mitigate macrophages' engulfment thus decelerating LNPs clearance, even though at the same time they can activate the immune system mostly through complement activation $[61,64,65]$. Cationic lipids have a net positive charge, which allows the efficient incorporation of negatively charged ONs and increases cellular uptake and endosomal escape. However, cationic lipids are susceptible to rapid clearance mediated by the reticuloendothelial system (RES) and their high positive charge is related to increased toxicity. To avoid these limitations, efforts were concentrated on the development of neutral lipids but with limited success [66]. The advent of ionizable amino lipids represents the turning point in the field. 
Cationic/ionizable amino lipids are negatively charged when protonated at a $\mathrm{pH}$ below their $\mathrm{pKa}$, ensuring high encapsulation efficiency of negatively charged ONs. Moreover, they are neutrally charged in physiological environments ( $\mathrm{pH}<\mathrm{LNPs} \mathrm{pKa}$ ), decreasing cytotoxicity and improving circulation. Finally, they are positively charged in an acidic environment (i.e., endosomes) leading to the association to anionic endosomal lipids and consequently the release of the payload in the cytosol $[61,64]$. Such formulations were demonstrated to be efficient in the in vitro delivery of siRNAs [67] and in vivo release of miRNAs [68-70], alone or in combination with other therapeutics, and ASOs [71].

LNPs have been studied for more than two decades as vehicles for ONs delivery; however, there are still several drawbacks limiting their use in humans. One example is represented by MRX34, a liposomal formulation of miRNA-34a mimic, which in 2013 entered the first in-human Phase I study for the treatment of hepatocellular carcinoma (HCC). Despite encouraging results obtained in an orthotopic mouse model of HCC [72] and in HCC-affected patients [73], a trial started in 2014 was prematurely closed due to serious immune-related adverse effects [74]. It is now known that LNPs can themselves induce toxicity and elicit an immune response [65,75]. To decrease these side effects, novel ionizable lipids, such as autotaxin (ATX), with a safer profile and higher miRNA deliver efficiency were developed [63].

\subsection{Polymeric Nanoparticles}

Polymeric NPs are less clinically advanced than lipid-based carriers but their integrity, their stability, and the possibility of being largely engineered make them interesting carriers for ON delivery (Figure 6B). Polymeric NPs are composed of synthetic or natural polymers. Among synthetic polymers, polyethyleneimine (PEI) was the most extensively studied being an effective gene transfection agent. The high number of amine groups present in its structure confers to PEI a positive charge, allowing strong affinity for ONs and facilitating interaction with the cell membrane. Even so, the high density of positive charges is related to in vivo toxicity and the activation of the immune system [76,77]. To avoid these issues, copolymeric structures, obtained through the association of PEI with a negatively charged biodegradable and biocompatible polymer such as poly(3hydroxybutyrate) (PHB) [78], poly-(D,L-lactide-co-glycolide) (PLGA) [79], or also PEG, demonstrated an improved biocompatibility and efficient miRNA delivery. Furthermore, the employment of polymers such as poly(2-dimethylaminoethyl acrylate) (PDMAEA), which are positively charged at physiological $\mathrm{pH}$ and degrades into negatively charged non-toxic polymers in water, may offer a valid alternative for siRNA protection against enzymatic degradation and their efficient delivery into cells [80,81].

Among synthetic polymer-based NPs, dendrimers were extensively studied as ON delivery systems. In detail, dendrimers are chemically and physically stable, highly branched, three-dimensional molecules, 1-10 nm in size [60]. What makes them excellent candidates for ON delivery is their ability to carry and protect large amounts of ONs from degradation; moreover, the protonation of the abundant tertiary amines present in their structure facilitates the release of the cargo through the disruption of the endosomal membrane [59]. The most employed dendrimers are derived from poly(amidoamine) (PAMAM), a synthetic hydrophilic, biocompatible, and non-immunogenic polymer $[59,60]$. Promising results on the fifth generation of PAMAM dendrimers (PAMAM G5) were obtained. PAMAM G5 were in fact demonstrated to deliver in vitro miRNAs in glioma cells [82], and to release siRNAs in HCC cells in vivo [83].

Natural polymers offer an alternative to synthetic ones. Among them, chitosan has gained great interest because of its high positive charge associated with biocompatibility, low immunogenicity, and low cytotoxicity [76]. For an effective transfection, the endosomal escape is fundamental. Chitosan can exploit its buffer capacity in a $\mathrm{pH}$ interval between 5 and 7 , promoting the rupture of endosomes after $72 \mathrm{~h}$ with the consequent release of the cargo in the cytoplasm [84]. The transfection efficiency of chitosan NPs also depends on its degree of deacetylation (DD) and molecular weight (MW) [76]. The DD 
determines the positive charge and the solubility of chitosan, the binding capacity, and the transfection efficiency. A DD higher than $80 \%$ is required for the release of siRNA [85]. Likewise, low MW polymer was reported to easily release siRNA in the cytoplasm and to favor endosomal escape with higher efficacy than the high MW counterpart [86]. Chitosan NPs were demonstrated to efficiently deliver miRNA when totally constituting the structure of vehicles [87] or as a copolymer with PLGA [88]. However, the transfection efficiency of chitosan is relatively low due to in vivo instability and insufficient cellular release.

\subsection{Inorganic Nanoparticles}

In the last decade, inorganic NPs (INPs) have been extensively studied because of their tunable size and surface properties, chemical and thermal stability, and low toxicity $[62,89]$. Of the INPs, gold NPs (AuNPs) are the most studied because they can be produced with low size dispersity and they can be functionalized by the creation of multifunctional monolayers to modulate cytotoxicity, biodistribution, and excretion [89]. ONs can interact with AuNPs through covalent or electrostatic interactions. Covalent attachment can be made just when this modification does not inhibit the biological activity of the cargo. Noncovalent bound ONs can be achieved by functionalizing AuNPs with amino acids (e.g., lysine dendron-coated AuNPs) or producing mixed-monolayer-protected or layerby-layer-fabricated AuNPs such as siRNA/PEI-AuNPs or PEI/siRNA/PEI/AuNPs [89]. AuNPs were also demonstrated to efficiently enhance stability of decoys ensuring their therapeutic effect against head and neck cancer (HNC) [90]. Regarding miRNAs, even though AuNPs were demonstrated to release these molecules per se in vitro in multiple myeloma (MM) cells [91], typically INPs suffer from low transfection efficiency related to the lack of condensation ability with ONs [92] (Figure 6C).

\subsection{Exosomes}

Exosomes are nanoscale extracellular vesicles (EVs) first described 25 years ago. They are natural carriers of mRNA, miRNA, and siRNA and are composed of a lipid bilayer derived from the inward budding of late endosomes of cells, from which they are released, and an inner aqueous core (Figure 6D). Notwithstanding they share similarities with the structure of liposomes, exosomes showed lower toxicity and immunogenicity, and also higher target specificity [93].

An important recent progression in the field is represented by the bioengineering of exosomes which can be loaded with specific therapeutic drugs to improve their biodistribution and safety profile [94]. Engineered exosomes were reported to specifically deliver siRNA in oral squamous cell carcinoma cells [95], pancreatic ductal adenocarcinoma cells [96], postoperative breast cancer-derived lung metastasis [97], human pancreatic cancer cells [98], gastric cancer cells [96], and lung cancer cells [99] resulting in the significant decrease of tumor growth in vitro and in vivo. Furthermore, miRNA were reported to be efficiently released by exosomes in breast cancer [100,101] and colon cancer cells [102].

\subsection{Hybrids}

All the previously described vehicles suffer from some limitations. These issues can be overcome with the production of advanced next-generation delivery systems based on the combination of different components taking advantage of the physical properties of both structures (Figure 6E). Hybrids based on PEI are the most frequently proposed as PEI has been demonstrated to be the most effective polymer in gene transfection. PAMAM, AuNPs, and LNPs were combined with PEI resulting in improved transfection efficiency [92]. However, the use of PEI is not always the best method to ameliorate such aspects; in fact, the high binding affinity between PEI linked to AuNPs and siRNA was demonstrated to limit the cytoplasm release of the silencing ON. Chitosan represents one alternative to this approach; in fact, modification of the surface of AuNPs with this polymer was demonstrated to efficiently deliver siRNA [103]. 
Furthermore, the combination of LNPs with AuNPs (AuroLNPs) showed promising results. Notably, AuroLNPs did not cause complement activation, evading recognition by the mononuclear phagocyte system (MPS) due to the neutral charge of the platform; moreover, AuroLNPs were demonstrated to accumulate in the tumor mass and to release siRNA in vivo significantly inhibiting the tumor growth in two human ovarian cancer models [104].

\section{Zebrafish (ZF) as an Animal Model to Mimic Human Cancer}

There are several approaches to generate human cancer in ZF (Danio rerio), such as the development of mutant and then transgenic fish lines, or transplantation of tumor cells $[105,106]$. Transgenic lines can be induced through chemical mutagenesis, irradiation mutagenesis, transposon-based, or viral vector insertional mutagenesis. However, until now, researchers forced the development of several cancer types by directly adding carcinogens to the water or acting into one-cell-stage ZF embryos, microinjecting exogenous DNA [107]. Interestingly, when exposed to carcinogens, ZF develops tumors in virtually all organs with similar histology to human tumors [108].

In regard to xenotransplantation, ZF models nowadays represent a well-known option for implementing strategies of personalized medicine, together with other models of patient-derived xenografts or patient-derived organoids [109,110]. The efficiency and the growth of human cancer cells in ZF was firstly reported in 2005 [111] when authors evidenced many similarities in the behavior of tumors developed in mammalian models, putting the basis for further employment of ZF into this field. When injecting foreign cells into an organism, the state of the immune system is one of the first things that must be considered. ZF's adaptive immune system does not reach maturity until 4-weeks post-fertilization, when immature $T$ and $B$ cells reach the thymus [112]. This lack of immune defense in ZF embryos allows the establishment of xenografts without the need of additional immunosuppression agents, facilitating tumor cells growth and reducing the variability. Furthermore, the times in which the animals are manipulated were significantly reduced [112,113]. Xenografts can be induced in adult ZF, but just after immune system ablation to avoid engraftment rejection. Methods applied to achieve immunosuppression in this context are similar to mouse model approaches [107]. Another strength of embryo ZF is the higher rapidity of cancer development if compared to adults; in fact, tumor formation was evidenced 2 days after the injection. Consequently, embryos could be employed in projects that demand rapidity, such as imaging cancer progression or screening processes. By contrast, adults offer a more realistic in vivo model, as all of their organs and immune systems are completely developed, but cancer establishment requires from 10-14 days to 1 month [114].

The development of xenograft tumor models was optimized by Haldi et al. who evaluated the impact of the site of injection, age of transplant recipients, the amount of injected cells, and post-injection ZF care [115]. In particular, depending on the developmental stage of the $\mathrm{ZF}$, the microinjection site of the tumor cells can vary. Numerous sites of injection, including the hindbrain ventricle [115] and intravenous routes [116,117], were tested, but the yolk sac $[115,118,119]$ in 2-day-old embryos was demonstrated to be an ideal approach. This is due to the yolk sac providing a large site to house transplanted cells and facilitates manual transplantation in comparison with other smaller regions, such as the duct of Cuvier, caudal vein, or heart [107]. Regarding larvae's care after xenotransplantation, a temperature of $32-36{ }^{\circ} \mathrm{C}$ was demonstrated to be optimal [115,120-122] because in this range both natural embryonic development of the ZF transplant avatar and satisfactory human cell survival and proliferation are ensured [120,121].

Xenotransplant in Danio rerio is also supported by the transparency of the embryos from fertilization to when pigmentation is initiated (at approximately $30-72 \mathrm{~h}$ post-fertilization (hpf)) and the tissues become denser [123]. This process can be easily inhibited by treating embryos with $N$-Phenylthiourea (PTU), a molecule which suppresses the production of melanin, allowing the direct imaging of animal development, organogenesis, and cancer 
progression, also enabling the tracking of transplanted cells-previously transfected with GFP or pretreated with fluorescent membrane stains—or fluorescent NPs [113]. Moreover, this interesting feature allows the live imaging of injected NPs in the bloodstream through fluorescence microscopy. Currently, the study of interaction between foreign structuresxeno-transplanted cells or NPs-and immune or blood cells is allowed by in vitro tests, such as synthetic microvascular network developed by Vu et al. [124]; the transparency of ZF larvae represents an important feature to translate this study into a more realistic system. In fact, the bloodstream of ZF is easily visualized in live imaging, permitting this kind of study. Through these methods, it is common and easy to successfully differentiate injected from non-injected embryos, although it is still challenging to obtain a reproducible volume and therefore number of cell or NPs administration [125]. However, there are particular characteristics of ZF that may be problematic. The most obvious shortcoming of $\mathrm{ZF}$ is that it is not a mammal and lacks a placenta, but also breast and lungs [121]. This characteristic impedes an entire category of experiments that should be performed in a different animal model, such as mice and rats. In addition, there is a difference in the incubation temperatures, while injected human cancer cells should be maintained at $37^{\circ} \mathrm{C}$, the optimal temperature for $\mathrm{ZF}$ is $28^{\circ} \mathrm{C}$. Thus, a compromise incubation temperature should be used, but possible metabolic changes could occur and should be considered [121,126].

Therefore, each methodology has several advantages and disadvantages, and experimentation should be planned to better address the aim of the study considering the ZF developmental stage, each one presenting some different benefits.

\section{ZF for In Vivo Characterization of New Drugs}

ZF embryo is rapidly becoming an attractive and prominent in vivo vertebrate model for the screening of new drugs, nano-bio materials, and NPs, in regard to their biodistribution, toxicity $[84,127,128]$, and therapeutic efficacy. ZF offers a variety of advantages as a desirable model for in vivo high-throughput drug screening. This is achieved through microscopic analysis platforms taking advantage of ZF translucency and its ability to be maintained in 96-well plates. The optical transparency of embryos not only offers exciting research opportunities, allowing visualization of the biodistribution of compounds at high resolution [128], but also permits the evaluation of other parameters, including a lower hatching rate, mortality, and malformations [127].

ZF represents a versatile animal model due to the possibility of testing new therapeutic strategies in different ways. Toxicity studies can be carried out by the dissolution of drugs in water or their direct injection into the egg, the embryo, or the adult fish [107]. In the first case, eggs and fishes are immerse in the solution containing the compound(s) and the exposure route (i.e., chorion and epidermis; epidermis; epidermis and intestine via ingestion) influences the uptake and biodistribution of particles in ZF embryos. The predominant route still remains the oral one, since uptake over an internal mucosal membrane occurs faster than over an intact dermal epithelial membrane. The main physicochemical factor accounting for uptake, internalization, and further distribution is the size of particles [129]. Regarding injection into embryos, these could be performed in the yolk or in the duct of Cuvier, in order to obtain a localized or diffused distribution, respectively. Instead, in adult ZF, there are additional exploitable sites of injection, such as the retroorbital or intra peritoneal routes. Generally, small drugs and NPs are mostly dissolved in water, while larger structures can be intravenously micro-injected, and, if previously labeled with a fluorescent dye, directly observed at the whole animal level [130] (Figure 7).

MPS represents an important player in the distribution of NPs in the body. In fact, the uptake by macrophages is generally considered to decrease the chances of NP accumulation in tumor sites and it is therefore considered a deleterious factor in terms of efficiency [131,132]. Early embryonic macrophages are already present in ZF embryos at $30 \mathrm{hpf}$ and additional cells, which define the mammalian MPS, can be found in adult ZF. Another important cell type that affects NP distribution is represented by endothelial cells which bind and take up NPs [131]. On these bases, the wide availability of transgenic ZF, 
in comparison to mouse models, allows the assessment of NP interactions with selectively fluorescent cells such as macrophages (e.g., $\mathrm{Tg}$ (mpeg:mcherry)) [133], endothelial cells (e.g., $\mathrm{Tg}$ (Fli1a:EGFP)y1) [134], and neutrophils (e.g., Tg(mpx: GFP)i114) [135]. Another important characteristic to take into account before starting an experiment with an animal model is the temperature. In fact, as mentioned above, ZFs are routinely maintained at $28^{\circ} \mathrm{C}$, which differs by 10 degrees from that of the mouse $\left(38^{\circ} \mathrm{C}\right)[136]$ and $9{ }^{\circ} \mathrm{C}$ from that of the human body $\left(37^{\circ} \mathrm{C}\right)$, the latter being the ideal temperature for tumor cell proliferation [121]. Even if, the variation of the temperature of around $\sim 10{ }^{\circ} \mathrm{C}$ did not show differences in the internalization behavior, at the moment there is still a paucity of information in this field, and more studies are needed to fully investigate cell membrane composition and behaviors at ZFs internal temperature.

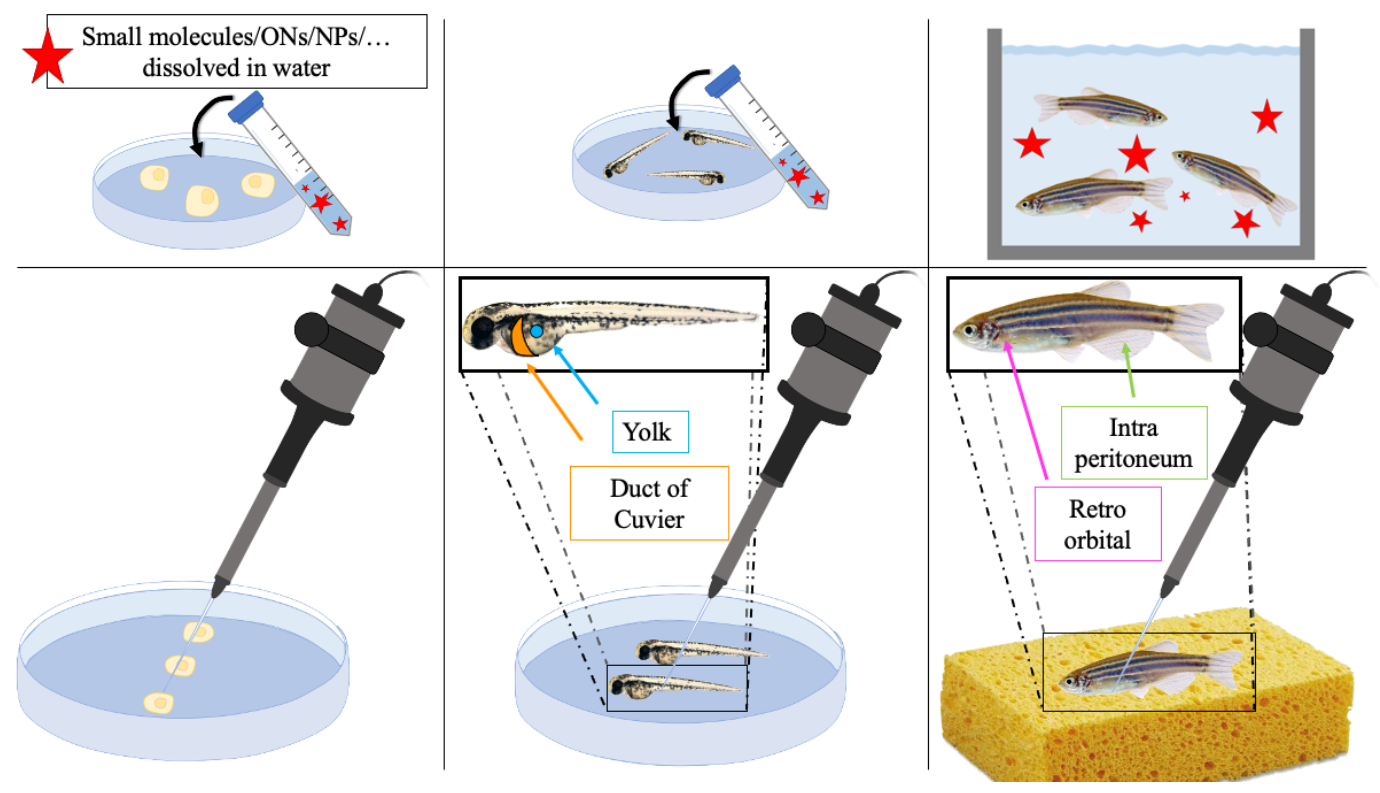

Figure 7. Schematic representation of different strategies to administer therapeutic compounds. ONs: oligonucleotides; NPs: nanoparticles.

In recent years, authors take advantage of ZF models to study and characterize ONs in both cancer and non-cancer related disorders. To the best of our knowledge, there is still paucity of information on this field. With regards to toxicity, some siRNAs injected into ZF embryos were demonstrated to induce morphological defects, abnormal development, and early death of animals [137], limiting the use of this model for these purposes. Regarding the efficacy of free ONs, a treatment based on ASOs was demonstrated to be efficient in restoring the exon skipping in a ZF model of retinitis pigmentosa [138], further suggesting the potential application of this model. Typically, ONs are not administered after dissolution in water, but they are fundamentally micro-injected in ZFs as free molecule or loaded inside NPs. In fact, ZF can be used for the characterization of ON-loaded NPs, which are known to change biodistribution of free molecules, consequently increasing their therapeutic effect and, in the meantime, decreasing toxicity. In fact, siRNA-loaded NPs were characterized in a ZF brain cancer model, demonstrating their efficacy through the decrease of cancer growth [139] and creating the basis for further studies.

\section{Conclusions and Perspectives}

ONs are rapidly growing as new therapeutic agents for the treatment of different forms of cancers; their versatility and the diverse chemical characteristics guarantee the possibility of targeting nucleic acids and proteins involved in either tumor development, progression, or both. Several issues have still to be solved for their clinical use but the development of specific delivery systems based on nanostructures allows overcoming most 
of them, showing a selective action of the $\mathrm{ON}$ in the tumor microenvironment. Moreover, the possibility to exploit new in vitro and in vivo models permits a rapid characterization of the new therapeutic approaches based on ONs; in this context ZF is obtaining popularity because of its capacity to provide strong results in a short period of time, in a system less complex than mice and particularly useful for the screening of new compounds or delivery systems (Figure 8).

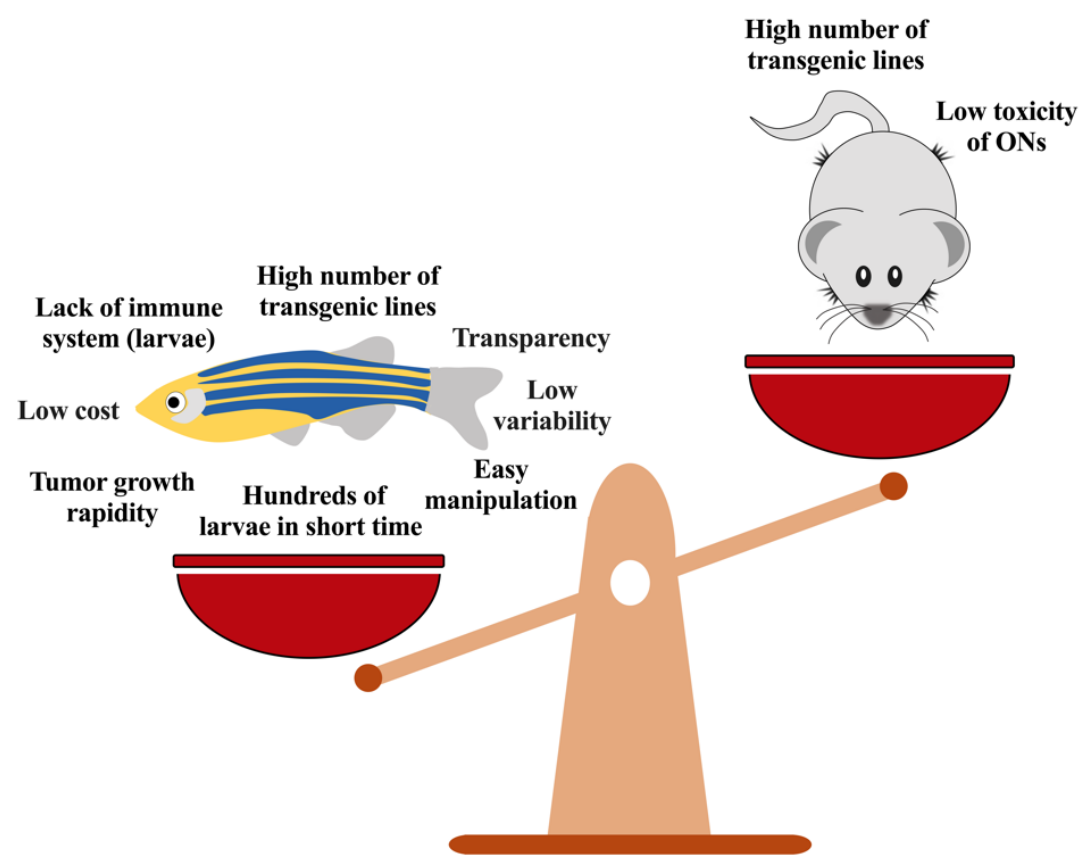

Figure 8. Zebrafish vs. mouse models. ONs: oligonucleotides.

Recent breakthroughs in vaccines based on mRNA exploit LNPs to guarantee nucleic acid protection but also to increase the delivery of mRNA vaccines in vivo [66]. Clinical studies clearly evidenced the potential results deriving from this approach, boosting research activities and clinical trials aiming to develop new therapeutic strategies, not only for the treatment of infectious diseases but also for other clinical manifestations, including cancer [63]. Several issues remain to be addressed in order to move to a prolonged or chronic treatment, linked, for examples, to the interaction of the nanostructures with the immune system of the patients; the formation of a protein corona opsonizing nanoparticles induces a rapid elimination of the delivery systems. The capacity to reduce this interaction and the possibility to better exploit efficient targeting agents remain important factors that have to be taken in consideration during the development of nanoparticle-based oligonucleotide delivery in cancer.

Taking together these aspects, NP-based delivery of ONs in the tumor microenvironment, with their characterization in ZF models, represents a future weapon for the treatment of several clinical manifestations; the development of effective delivery systems remains a pivotal issue and the ZF model contribute to their characterization, demonstrating to be an ideal approach for the screening of new therapeutics for the treatment of cancer.

Author Contributions: Writing—original draft preparation, S.B., S.C. and M.D.B.; writing—review and editing, S.C., S.B., M.D.B., G.T. and P.M.; supervision S.C., M.D.B. and P.M.; funding acquisition, P.M.; figure preparation, S.B. and S.C. All authors have read and agreed to the published version of the manuscript.

Funding: This work was supported by the Italian Association for Cancer Research (AIRC) and Fondo di Ricerca di Ateneo 2018-University of Trieste. 
Institutional Review Board Statement: Not applicable.

Informed Consent Statement: Not applicable.

Data Availability Statement: Not applicable.

Conflicts of Interest: The authors declare no conflict of interest.

\section{References}

1. Scherman, D.; Rousseau, A.; Bigey, P.; Escriou, V. Genetic Pharmacology: Progresses in SiRNA Delivery and Therapeutic Applications. Gene Ther. 2017, 24, 151-156. [CrossRef]

2. Xiong, H.; Veedu, R.N.; Diermeier, S.D. Recent Advances in Oligonucleotide Therapeutics in Oncology. Int. J. Mol. Sci. 2021, 22, 3295. [CrossRef]

3. Smith, C.; Zain, R. Therapeutic Oligonucleotides: State of the Art. Annu. Rev. Pharmacol. Toxicol. 2019, 59, 605-630. [CrossRef]

4. Wittrup, A.; Lieberman, J. Knocking down Disease: A Progress Report on SiRNA Therapeutics. Nat. Rev. Genet. 2015, 16, 543-552. [CrossRef]

5. Lorenzer, C.; Dirin, M.; Winkler, A.-M.; Baumann, V.; Winkler, J. Going beyond the Liver: Progress and Challenges of Targeted Delivery of SiRNA Therapeutics. J. Controlled Release 2015, 203, 1-15. [CrossRef]

6. Giudice, V.; Mensitieri, F.; Izzo, V.; Filippelli, A.; Selleri, C. Aptamers and Antisense Oligonucleotides for Diagnosis and Treatment of Hematological Diseases. Int. J. Mol. Sci. 2020, 21, 3252. [CrossRef]

7. Statello, L.; Ali, M.; Kanduri, C. In Vivo Administration of Therapeutic Antisense Oligonucleotides. Methods Mol. Biol. 2021, 2254, 273-282. [CrossRef]

8. Wu, H.; Lima, W.F.; Zhang, H.; Fan, A.; Sun, H.; Crooke, S.T. Determination of the Role of the Human RNase H1 in the Pharmacology of DNA-like Antisense Drugs. J. Biol. Chem. 2004, 279, 17181-17189. [CrossRef] [PubMed]

9. Zhang, L.; Vickers, T.A.; Sun, H.; Liang, X.; Crooke, S.T. Binding of Phosphorothioate Oligonucleotides with RNase H1 Can Cause Conformational Changes in the Protein and Alter the Interactions of RNase H1 with Other Proteins. Nucleic Acids Res. 2021, 49, 2721-2739. [CrossRef] [PubMed]

10. Monia, B.P.; Lesnik, E.A.; Gonzalez, C.; Lima, W.F.; McGee, D.; Guinosso, C.J.; Kawasaki, A.M.; Cook, P.D.; Freier, S.M. Evaluation of 2'-Modified Oligonucleotides Containing 2'-Deoxy Gaps as Antisense Inhibitors of Gene Expression. J. Biol. Chem. 1993, 268, 14514-14522. [CrossRef]

11. Larrouy, B.; Bolziau, C.; Sproat, B.; Toulmé, J.-J. RNase H Is Responsible for the Non-Specific Inhibition of in Vitro Translation by 2'-O-Alkyl Chimeric Oligonucleotides: High Affinity or Selectivity, a Dilemma to Design Antisense Oligomers. Nucleic Acids Res. 1995, 23, 3434-3440. [CrossRef]

12. Liang, X.-H.; Sun, H.; Nichols, J.G.; Crooke, S.T. RNase H1-Dependent Antisense Oligonucleotides Are Robustly Active in Directing RNA Cleavage in Both the Cytoplasm and the Nucleus. Mol. Ther. 2017, 25, 2075-2092. [CrossRef]

13. Dominski, Z.; Kole, R. Restoration of Correct Splicing in Thalassemic Pre-MRNA by Antisense Oligonucleotides. Proc. Natl. Acad. Sci. USA 1993, 90, 8673-8677. [CrossRef] [PubMed]

14. Singh, R.N.; Singh, N.N. Mechanism of splicing regulation of spinal muscular atrophy genes. In RNA Metabolism in Neurodegenerative Diseases; Sattler, R., Donnelly, C.J., Eds.; Advances in Neurobiology; Springer International Publishing: Cham, Switzerland, 2018; Volume 20, pp. 31-61. [CrossRef]

15. Wan, L.; Dreyfuss, G. Splicing-Correcting Therapy for SMA. Cell 2017, 170, 5. [CrossRef] [PubMed]

16. Aartsma-Rus, A.; Straub, V.; Hemmings, R.; Haas, M.; Schlosser-Weber, G.; Stoyanova-Beninska, V.; Mercuri, E.; Muntoni, F.; Sepodes, B.; Vroom, E.; et al. Development of Exon Skipping Therapies for Duchenne Muscular Dystrophy: A Critical Review and a Perspective on the Outstanding Issues. Nucleic Acid Ther. 2017, 27, 251-259. [CrossRef]

17. Baker, B.F.; Lot, S.S.; Condon, T.P.; Cheng-Flournoy, S.; Lesnik, E.A.; Sasmor, H.M.; Bennett, C.F. 2'-O-(2-Methoxy)Ethyl-Modified Anti-Intercellular Adhesion Molecule 1 (ICAM-1) Oligonucleotides Selectively Increase the ICAM-1 MRNA Level and Inhibit Formation of the ICAM-1 Translation Initiation Complex in Human Umbilical Vein Endothelial Cells. J. Biol. Chem. 1997, 272, 11994-12000. [CrossRef]

18. Boiziau, C.; Kurfurst, R.; Cazenave, C.; Roig, V.; Thuong, N.T.; Toulmé, J.-J. Inhibition of Translation Initiation by Antisense Oligonucleotides via an RNase-H Independent Mechanism. Nucleic Acids Res. 1991, 19, 1113-1119. [CrossRef]

19. Calvo, S.E.; Pagliarini, D.J.; Mootha, V.K. Upstream Open Reading Frames Cause Widespread Reduction of Protein Expression and Are Polymorphic among Humans. Proc. Natl. Acad. Sci. USA 2009, 106, 7507-7512. [CrossRef]

20. Elbashir, S.M.; Harborth, J.; Lendeckel, W.; Yalcin, A.; Weber, K.; Tuschl, T. Duplexes of 21-Nucleotide RNAs Mediate RNA Interference in Cultured Mammalian Cells. Nature 2001, 411, 494-498. [CrossRef]

21. Liu, J.; Carmell, M.A.; Rivas, F.V.; Marsden, C.G.; Thomson, J.M.; Song, J.-J.; Hammond, S.M.; Joshua-Tor, L.; Hannon, G.J. Argonaute2 Is the Catalytic Engine of Mammalian RNAi. Science 2004, 305, 1437-1441. [CrossRef] [PubMed]

22. Roberts, T.C. The microRNA machinery. In microRNA: Basic Science; Santulli, G., Ed.; Advances in Experimental Medicine and Biology; Springer International Publishing: Cham, Switzerland, 2015; Volume 887, pp. 15-30. ISBN 978-3-319-22379-7. [CrossRef]

23. Schürmann, N.; Trabuco, L.G.; Bender, C.; Russell, R.B.; Grimm, D. Molecular Dissection of Human Argonaute Proteins by DNA Shuffling. Nat. Struct. Mol. Biol. 2013, 20, 818-826. [CrossRef] 
24. Kim, D.-H.; Behlke, M.A.; Rose, S.D.; Chang, M.-S.; Choi, S.; Rossi, J.J. Synthetic DsRNA Dicer Substrates Enhance RNAi Potency and Efficacy. Nat. Biotechnol. 2005, 23, 222-226. [CrossRef]

25. Bramsen, J.B.; Laursen, M.B.; Damgaard, C.K.; Lena, S.W.; Ravindra Babu, B.; Wengel, J.; Kjems, J. Improved Silencing Properties Using Small Internally Segmented Interfering RNAs. Nucleic Acids Res. 2007, 35, 5886-5897. [CrossRef] [PubMed]

26. Yu, D.; Pendergraff, H.; Liu, J.; Kordasiewicz, H.B.; Cleveland, D.W.; Swayze, E.E.; Lima, W.F.; Crooke, S.T.; Prakash, T.P.; Corey, D.R. Single-Stranded RNAs Use RNAi to Potently and Allele-Selectively Inhibit Mutant Huntingtin Expression. Cell 2012, 150, 895-908. [CrossRef] [PubMed]

27. Byrne, M.; Tzekov, R.; Wang, Y.; Rodgers, A.; Cardia, J.; Ford, G.; Holton, K.; Pandarinathan, L.; Lapierre, J.; Stanney, W.; et al. Novel Hydrophobically Modified Asymmetric RNAi Compounds (Sd-RxRNA) Demonstrate Robust Efficacy in the Eye. J. Ocul. Pharmacol. Ther. 2013, 29, 855-864. [CrossRef] [PubMed]

28. Yu, L.; Liang, D.; Chen, C.; Tang, X. Caged SiRNAs with Single CRGD Modification for Photoregulation of Exogenous and Endogenous Gene Expression in Cells and Mice. Biomacromolecules 2018, 19, 2526-2534. [CrossRef]

29. Alterman, J.F.; Godinho, B.M.D.C.; Hassler, M.R.; Ferguson, C.M.; Echeverria, D.; Sapp, E.; Haraszti, R.A.; Coles, A.H.; Conroy, F.; Miller, R.; et al. A Divalent SiRNA Chemical Scaffold for Potent and Sustained Modulation of Gene Expression throughout the Central Nervous System. Nat. Biotechnol. 2019, 37, 884-894. [CrossRef]

30. Krützfeldt, J.; Rajewsky, N.; Braich, R.; Rajeev, K.G.; Tuschl, T.; Manoharan, M.; Stoffel, M. Silencing of MicroRNAs In Vivo with 'Antagomirs'. Nature 2005, 438, 685-689. [CrossRef]

31. Krützfeldt, J.; Kuwajima, S.; Braich, R.; Rajeev, K.G.; Pena, J.; Tuschl, T.; Manoharan, M.; Stoffel, M. Specificity, Duplex Degradation and Subcellular Localization of Antagomirs. Nucleic Acids Res. 2007, 35, 2885-2892. [CrossRef]

32. Lee, J.F.; Stoval, G.M.; Ellington, A.D. Aptamer Therapeutics Advance. Curr. Opin. Chem. Biol. 2006, 10, 282-289. [CrossRef]

33. Shigdar, S.; Schrand, B.; Giangrande, P.H.; de Franciscis, V. Aptamers: Cutting Edge of Cancer Therapies. Mol. Ther. 2021. [CrossRef]

34. Byun, J. Recent Progress and Opportunities for Nucleic Acid Aptamers. Life 2021, 11, 193. [CrossRef]

35. Tuerk, C.; Gold, L. Systematic Evolution of Ligands by Exponential Enrichment: RNA Ligands to Bacteriophage T4 DNA Polymerase. Science 1990, 249, 505-510. [CrossRef]

36. Robertson, D.; Joyce, G. Selection In Vitro of an RNA Enzyme That Specifically Cleaves Single-Stranded DNA. Nature 1990, 344, 467-468. [CrossRef] [PubMed]

37. Ellington, A.D.; Szostak, J.W. In Vitro Selection of RNA Molecules That Bind Specific Ligands. Nature 1990, $346,818-822$. [CrossRef] [PubMed]

38. Oberthür, D.; Achenbach, J.; Gabdulkhakov, A.; Buchner, K.; Maasch, C.; Falke, S.; Rehders, D.; Klussmann, S.; Betzel, C. Crystal Structure of a Mirror-Image L-RNA Aptamer (Spiegelmer) in Complex with the Natural L-Protein Target CCL2. Nat. Commun. 2015, 6, 6923. [CrossRef] [PubMed]

39. Mann, M.J. Transcription Factor Decoys: A New Model for Disease Intervention. Ann. N. Y. Acad. Sci. 2005, 1058, 128-139. [CrossRef] [PubMed]

40. Hecker, M.; Wagner, A.H. Transcription Factor Decoy Technology: A Therapeutic Update. Biochem. Pharmacol. 2017, 144, 29-34. [CrossRef]

41. Juliano, R.L. Intracellular Trafficking and Endosomal Release of Oligonucleotides: What We Know and What We Don't. Nucleic Acid Ther. 2018, 28, 166-177. [CrossRef]

42. Crooke, S.T.; Wang, S.; Vickers, T.A.; Shen, W.; Liang, X. Cellular Uptake and Trafficking of Antisense Oligonucleotides. Nat. Biotechnol. 2017, 35, 230-237. [CrossRef]

43. Liang, X.; Sun, H.; Shen, W.; Stanley, T.C. Identification and Characterization of Intracellular Proteins That Bind Oligonucleotides with Phosphorothioate Linkages. Nucleic Acids Res. 2015, 43, 2927-2945. [CrossRef]

44. Doherty, G.J.; McMahon, H.T. Mechanisms of Endocytosis. Annu. Rev. Biochem. 2009, 78, 857-902. [CrossRef]

45. Marchese, A.; Paing, M.M.; Temple, B.R.S.; Trejo, J. G Protein-Coupled Receptor Sorting to Endosomes and Lysosomes. Annu. Rev. Pharmacol. Toxicol. 2008, 48, 601-629. [CrossRef]

46. Lajoie, P.; Nabi, I.R. Lipid rafts, caveolae, and their endocytosis. In International Review of Cell and Molecular Biology; Elsevier: Amsterdam, The Netherlands, 2010; Volume 282, pp. 135-163. [CrossRef]

47. Alam, M.R.; Ming, X.; Dixit, V.; Fisher, M.; Chen, X.; Juliano, R.L. The Biological Effect of an Antisense Oligonucleotide Depends on Its Route of Endocytosis and Trafficking. Oligonucleotides 2010, 20, 103-109. [CrossRef]

48. Koller, E.; Vincent, T.M.; Chappell, A.; De, S.; Manoharan, M.; Bennett, C.F. Mechanisms of Single-Stranded Phosphorothioate Modified Antisense Oligonucleotide Accumulation in Hepatocytes. Nucleic Acids Res. 2011, 39, 4795-4807. [CrossRef]

49. Huotari, J.; Helenius, A. Endosome Maturation: Endosome Maturation. EMBO J. 2011, 30, 3481-3500. [CrossRef] [PubMed]

50. Goldenring, J.R. Recycling Endosomes. Curr. Opin. Cell Biol. 2015, 35, 117-122. [CrossRef] [PubMed]

51. Luzio, J.P.; Pryor, P.R.; Bright, N.A. Lysosomes: Fusion and Function. Nat. Rev. Mol. Cell Biol. 2007, 8, 622-632. [CrossRef] [PubMed]

52. Mariño, G.; Madeo, F.; Kroemer, G. Autophagy for Tissue Homeostasis and Neuroprotection. Curr. Opin. Cell Biol. 2011, 23, 198-206. [CrossRef] [PubMed]

53. Johannes, L.; Wunder, C. Retrograde Transport: Two (or More) Roads Diverged in an Endosomal Tree? Traffic 2011, 12, 956-962. [CrossRef] [PubMed] 
54. Sandvig, K.; Skotland, T.; van Deurs, B.; Klokk, T.I. Retrograde Transport of Protein Toxins through the Golgi Apparatus. Histochem. Cell Biol. 2013, 140, 317-326. [CrossRef]

55. Roberts, T.C.; Langer, R.; Wood, M.J.A. Advances in Oligonucleotide Drug Delivery. Nat. Rev. Drug Discov. 2020, 19, 673-694. [CrossRef]

56. Stein, C.A.; Hansen, J.B.; Lai, J.; Wu, S.; Voskresenskiy, A.; Høg, A.; Worm, J.; Hedtjärn, M.; Souleimanian, N.; Miller, P.; et al. Efficient Gene Silencing by Delivery of Locked Nucleic Acid Antisense Oligonucleotides, Unassisted by Transfection Reagents. Nucleic Acids Res. 2010, 38, e3. [CrossRef]

57. Biscans, A.; Caiazzi, J.; Davis, S.; McHugh, N.; Sousa, J.; Khvorova, A. The Chemical Structure and Phosphorothioate Content of Hydrophobically Modified SiRNAs Impact Extrahepatic Distribution and Efficacy. Nucleic Acids Res. 2020, 48, 7665-7680. [CrossRef] [PubMed]

58. Hammond, S.M.; Aartsma-Rus, A.; Alves, S.; Borgos, S.E.; Buijsen, R.A.M.; Collin, R.W.J.; Covello, G.; Denti, M.A.; Desviat, L.R.; Echevarría, L.; et al. Delivery of Oligonucleotide-based Therapeutics: Challenges and Opportunities. EMBO Mol. Med. 2021, 13. [CrossRef] [PubMed]

59. Palmerston Mendes, L.; Pan, J.; Torchilin, V. Dendrimers as Nanocarriers for Nucleic Acid and Drug Delivery in Cancer Therapy. Molecules 2017, 22, 1401. [CrossRef] [PubMed]

60. Tarach, P.; Janaszewska, A. Recent Advances in Preclinical Research Using PAMAM Dendrimers for Cancer Gene Therapy. Int. J. Mol. Sci. 2021, 22, 2912. [CrossRef] [PubMed]

61. Moss, K.H.; Popova, P.; Hadrup, S.R.; Astakhova, K.; Taskova, M. Lipid Nanoparticles for Delivery of Therapeutic RNA Oligonucleotides. Mol. Pharm. 2019, 16, 2265-2277. [CrossRef]

62. de la Fuente, I.F.; Sawant, S.S.; Tolentino, M.Q.; Corrigan, P.M.; Rouge, J.L. Viral Mimicry as a Design Template for Nucleic Acid Nanocarriers. Front. Chem. 2021, 9, 613209. [CrossRef]

63. Thi, T.T.H.; Suys, E.J.A.; Lee, J.S.; Nguyen, D.H.; Park, K.D.; Truong, N.P. Lipid-Based Nanoparticles in the Clinic and Clinical Trials: From Cancer Nanomedicine to COVID-19 Vaccines. Vaccines 2021, 9, 359. [CrossRef]

64. Tam, Y.; Chen, S.; Cullis, P. Advances in Lipid Nanoparticles for SiRNA Delivery. Pharmaceutics 2013, 5, 498-507. [CrossRef]

65. Inglut, C.T.; Sorrin, A.J.; Kuruppu, T.; Vig, S.; Cicalo, J.; Ahmad, H.; Huang, H.-C. Immunological and Toxicological Considerations for the Design of Liposomes. Nanomaterials 2020, 10, 190. [CrossRef]

66. Pilkington, E.H.; Suys, E.J.A.; Trevaskis, N.L.; Wheatley, A.K.; Zukancic, D.; Algarni, A.; Al-Wassiti, H.; Davis, T.P.; Pouton, C.W.; Kent, S.J.; et al. From Influenza to COVID-19: Lipid Nanoparticle MRNA Vaccines at the Frontiers of Infectious Diseases. Acta Biomater. 2021. [CrossRef]

67. Jyotsana, N.; Sharma, A.; Chaturvedi, A.; Budida, R.; Scherr, M.; Kuchenbauer, F.; Lindner, R.; Noyan, F.; Sühs, K.-W.; Stangel, M.; et al. Lipid Nanoparticle-Mediated SiRNA Delivery for Safe Targeting of Human CML in Vivo. Ann. Hematol. 2019, 98, 1905-1918. [CrossRef] [PubMed]

68. Hsu, S.; Yu, B.; Wang, X.; Lu, Y.; Schmidt, C.R.; Lee, R.J.; Lee, L.J.; Jacob, S.T.; Ghoshal, K. Cationic Lipid Nanoparticles for Therapeutic Delivery of SiRNA and MiRNA to Murine Liver Tumor. Nanomed. Nanotechnol. Biol. Med. 2013, 9, 1169-1180. [CrossRef]

69. Xu, F.; Liao, J.-Z.; Xiang, G.-Y.; Zhao, P.-X.; Ye, F.; Zhao, Q.; He, X.-X. MiR-101 and Doxorubicin Codelivered by Liposomes Suppressing Malignant Properties of Hepatocellular Carcinoma. Cancer Med. 2017, 6, 651-661. [CrossRef]

70. Wang, L.; Liang, T.-T. CD59 Receptor Targeted Delivery of MiRNA-1284 and Cisplatin-Loaded Liposomes for Effective Therapeutic Efficacy against Cervical Cancer Cells. AMB Express 2020, 10, 54. [CrossRef] [PubMed]

71. Zhang, C.; Pei, J.; Kumar, D.; Sakabe, I.; Boudreau, H.; Gokhale, P.; Kasid, U. Antisense Oligonucleotides: Target Validation and Development of Systemically Delivered Therapeutic Nanoparticles. Methods Mol. Biol 2007, 361, 163-185. [CrossRef] [PubMed]

72. Ling, H.; Fabbri, M.; Calin, G.A. MicroRNAs and Other Non-Coding RNAs as Targets for Anticancer Drug Development. Nat. Rev. Drug Discov. 2013, 12, 847-865. [CrossRef]

73. Beg, M.S.; Brenner, A.J.; Sachdev, J.; Borad, M.; Kang, Y.-K.; Stoudemire, J.; Smith, S.; Bader, A.G.; Kim, S.; Hong, D.S. Phase I Study of MRX34, a Liposomal MiR-34a Mimic, Administered Twice Weekly in Patients with Advanced Solid Tumors. Investig. New Drugs 2017, 35, 180-188. [CrossRef]

74. Hong, D.S.; Kang, Y.-K.; Borad, M.; Sachdev, J.; Ejadi, S.; Lim, H.Y.; Brenner, A.J.; Park, K.; Lee, J.-L.; Kim, T.-Y.; et al. Phase 1 Study of MRX34, a Liposomal MiR-34a Mimic, in Patients with Advanced Solid Tumours. Br. J. Cancer 2020, 122, 1630-1637. [CrossRef]

75. Wang, Y.; Miao, L.; Satterlee, A.; Huang, L. Delivery of Oligonucleotides with Lipid Nanoparticles. Adv. Drug Deliv. Rev. 2015, 87, 68-80. [CrossRef]

76. Thomas, T.J.; Tajmir-Riahi, H.-A.; Pillai, C.K.S. Biodegradable Polymers for Gene Delivery. Molecules 2019, 24, 3744. [CrossRef] [PubMed]

77. Gómez-Aguado, I.; Rodríguez-Castejón, J.; Vicente-Pascual, M.; Rodríguez-Gascón, A.; Solinís, M.Á.; del Pozo-Rodríguez, A. Nanomedicines to Deliver MRNA: State of the Art and Future Perspectives. Nanomaterials 2020, 10, 364. [CrossRef] [PubMed]

78. Conte, R.; Valentino, A.; Di Cristo, F.; Peluso, G.; Cerruti, P.; Di Salle, A.; Calarco, A. Cationic Polymer Nanoparticles-Mediated Delivery of MiR-124 Impairs Tumorigenicity of Prostate Cancer Cells. Int. J. Mol. Sci. 2020, 21, 869. [CrossRef] [PubMed]

79. Liang, G.; Zhu, Y.; Jing, A.; Wang, J.; Hu, F.; Feng, W.; Xiao, Z.; Chen, B. Cationic MicroRNA-Delivering Nanocarriers for Efficient Treatment of Colon Carcinoma in Xenograft Model. Gene Ther. 2016, 23, 829-838. [CrossRef] [PubMed] 
80. Truong, N.P.; Jia, Z.; Burgess, M.; Payne, L.; McMillan, N.A.J.; Monteiro, M.J. Self-Catalyzed Degradable Cationic Polymer for Release of DNA. Biomacromolecules 2011, 12, 3540-3548. [CrossRef]

81. Truong, N.P.; Gu, W.; Prasadam, I.; Jia, Z.; Crawford, R.; Xiao, Y.; Monteiro, M.J. An Influenza Virus-Inspired Polymer System for the Timed Release of SiRNA. Nat. Commun. 2013, 4, 1902. [CrossRef] [PubMed]

82. Ren, Y.; Kang, C.-S.; Yuan, X.-B.; Zhou, X.; Xu, P.; Han, L.; Wang, G.X.; Jia, Z.; Zhong, Y.; Yu, S.; et al. Co-Delivery of as-MiR-21 and 5-FU by Poly(Amidoamine) Dendrimer Attenuates Human Glioma Cell Growth in Vitro. J. Biomater. Sci. Polym. Ed. 2010, 21, 303-314. [CrossRef] [PubMed]

83. Rajasekaran, D.; Srivastava, J.; Ebeid, K.; Gredler, R.; Akiel, M.; Jariwala, N.; Robertson, C.L.; Shen, X.-N.; Siddiq, A.; Fisher, P.B.; et al. Combination of Nanoparticle-Delivered SiRNA for Astrocyte Elevated Gene-1 (AEG-1) and All-Trans. Retinoic Acid (ATRA): An Effective Therapeutic Strategy for Hepatocellular Carcinoma (HCC). Bioconjug. Chem. 2015, 26, 1651-1661. [CrossRef] [PubMed]

84. Rizeq, B.R.; Younes, N.N.; Rasool, K.; Nasrallah, G.K. Synthesis, Bioapplications, and Toxicity Evaluation of Chitosan-Based Nanoparticles. Int. J. Mol. Sci. 2019, 20, 5776. [CrossRef]

85. Cao, Y.; Tan, Y.F.; Wong, Y.S.; Liew, M.W.J.; Venkatraman, S. Recent Advances in Chitosan-Based Carriers for Gene Delivery. Mar. Drugs 2019, 17, 381. [CrossRef]

86. Tezgel, Ö.; Szarpak-Jankowska, A.; Arnould, A.; Auzély-Velty, R.; Texier, I. Chitosan-Lipid Nanoparticles (CS-LNPs): Application to SiRNA Delivery. J. Colloid Interface Sci. 2018, 510, 45-56. [CrossRef]

87. Kaban, K.; Salva, E.; Akbuga, J. In Vitro Dose Studies on Chitosan Nanoplexes for MicroRNA Delivery in Breast Cancer Cells. Nucleic Acid Ther. 2017, 27, 45-55. [CrossRef] [PubMed]

88. Cosco, D.; Cilurzo, F.; Maiuolo, J.; Federico, C.; Di Martino, M.T.; Cristiano, M.C.; Tassone, P.; Fresta, M.; Paolino, D. Delivery of MiR-34a by Chitosan/PLGA Nanoplexes for the Anticancer Treatment of Multiple Myeloma. Sci. Rep. 2015, 5, 17579. [CrossRef] [PubMed]

89. Ding, Y.; Jiang, Z.; Saha, K.; Kim, C.S.; Kim, S.T.; Landis, R.F.; Rotello, V.M. Gold Nanoparticles for Nucleic Acid Delivery. Mol. Ther. 2014, 22, 1075-1083. [CrossRef]

90. Zhang, S.; Gupta, S.; Fitzgerald, T.J.; Bogdanov, A.A. Dual Radiosensitization and Anti-STAT3 Anti-Proliferative Strategy Based on Delivery of Gold Nanoparticle-Oligonucleotide Nanoconstructs to Head and Neck Cancer Cells. Nanotheranostics 2018, 2, 1-11. [CrossRef] [PubMed]

91. Crew, E.; Rahman, S.; Razzak-Jaffar, A.; Mott, D.; Kamundi, M.; Yu, G.; Tchah, N.; Lee, J.; Bellavia, M.; Zhong, C.-J. MicroRNA Conjugated Gold Nanoparticles and Cell Transfection. Anal. Chem. 2012, 84, 26-29. [CrossRef]

92. Gigante, A.; Li, M.; Junghänel, S.; Hirschhäuser, C.; Knauer, S.; Schmuck, C. Non-Viral Transfection Vectors: Are Hybrid Materials the Way Forward? MedChem Comm 2019, 10, 1692-1718. [CrossRef] [PubMed]

93. Shahabipour, F.; Barati, N.; Johnston, T.P.; Derosa, G.; Maffioli, P.; Sahebkar, A. Exosomes: Nanoparticulate Tools for RNA Interference and Drug Delivery. J. Cell. Physiol. 2017, 232, 1660-1668. [CrossRef]

94. Syn, N.L.; Wang, L.; Chow, E.K.-H.; Lim, C.T.; Goh, B.-C. Exosomes in Cancer Nanomedicine and Immunotherapy: Prospects and Challenges. Trends Biotechnol. 2017, 35, 665-676. [CrossRef] [PubMed]

95. Kase, Y.; Uzawa, K.; Wagai, S.; Yoshimura, S.; Yamamoto, J.-I.; Toeda, Y.; Okubo, M.; Eizuka, K.; Ando, T.; Nobuchi, T.; et al. Engineered Exosomes Delivering Specific Tumor-Suppressive RNAi Attenuate Oral Cancer Progression. Sci. Rep. 2021, $11,5897$. [CrossRef] [PubMed]

96. Zhou, W.; Zhou, Y.; Chen, X.; Ning, T.; Chen, H.; Guo, Q.; Zhang, Y.; Liu, P.; Zhang, Y.; Li, C.; et al. Pancreatic CancerTargeting Exosomes for Enhancing Immunotherapy and Reprogramming Tumor Microenvironment. Biomaterials 2021, 268, 120546. [CrossRef] [PubMed]

97. Zhao, L.; Gu, C.; Gan, Y.; Shao, L.; Chen, H.; Zhu, H. Exosome-Mediated SiRNA Delivery to Suppress Postoperative Breast Cancer Metastasis. J. Control. Release 2020, 318, 1-15. [CrossRef]

98. Tao, H.; Xu, H.; Zuo, L.; Li, C.; Qiao, G.; Guo, M.; Zheng, L.; Leitgeb, M.; Lin, X. Exosomes-Coated Bcl-2 SiRNA Inhibits the Growth of Digestive System Tumors Both In Vitro and In Vivo. Int. J. Biol. Macromol. 2020, 161, 470-480. [CrossRef]

99. Bai, J.; Duan, J.; Liu, R.; Du, Y.; Luo, Q.; Cui, Y.; Su, Z.; Xu, J.; Xie, Y.; Lu, W. Engineered Targeting TLyp-1 Exosomes as Gene Therapy Vectors for Efficient Delivery of SiRNA into Lung Cancer Cells. Asian J. Pharm. Sci. 2020, 15, 461-471. [CrossRef]

100. Ohno, S.; Takanashi, M.; Sudo, K.; Ueda, S.; Ishikawa, A.; Matsuyama, N.; Fujita, K.; Mizutani, T.; Ohgi, T.; Ochiya, T.; et al. Systemically Injected Exosomes Targeted to EGFR Deliver Antitumor MicroRNA to Breast Cancer Cells. Mol. Ther. 2013, 21, 185-191. [CrossRef]

101. Naseri, Z.; Kazemi Oskuee, R.; Jaafari, M.R.; Forouzandeh, M. Exosome-Mediated Delivery of Functionally Active MiRNA-142-3p Inhibitor Reduces Tumorigenicity of Breast Cancer in Vitro and in Vivo. Int. J. Nanomed. 2018, 13, 7727-7747. [CrossRef]

102. Liang, G.; Zhu, Y.; Ali, D.J.; Tian, T.; Xu, H.; Si, K.; Sun, B.; Chen, B.; Xiao, Z. Engineered Exosomes for Targeted Co-Delivery of MiR-21 Inhibitor and Chemotherapeutics to Reverse Drug Resistance in Colon Cancer. J. Nanobiotechnol. 2020, 18, 10. [CrossRef]

103. Shaabani, E.; Sharifiaghdam, M.; De Keersmaecker, H.; De Rycke, R.; De Smedt, S.; Faridi-Majidi, R.; Braeckmans, K.; Fraire, J.C. Layer by Layer Assembled Chitosan-Coated Gold Nanoparticles for Enhanced SiRNA Delivery and Silencing. Int. J. Mol. Sci. 2021, 22, 831. [CrossRef] 
104. Hossen, M.N.; Wang, L.; Chinthalapally, H.R.; Robertson, J.D.; Fung, K.-M.; Wilhelm, S.; Bieniasz, M.; Bhattacharya, R.; Mukherjee, P. Switching the Intracellular Pathway and Enhancing the Therapeutic Efficacy of Small Interfering RNA by Auroliposome. Sci. Adv. 2020, 6, eaba5379. [CrossRef]

105. Raby, L.; Völkel, P.; Le Bourhis, X.; Angrand, P.-O. Genetic Engineering of Zebrafish in Cancer Research. Cancers 2020, $12,2168$. [CrossRef] [PubMed]

106. Hason, M.; Bartůněk, P. Zebrafish Models of Cancer-New Insights on Modeling Human Cancer in a Non-Mammalian Vertebrate. Genes 2019, 10, 935. [CrossRef] [PubMed]

107. Letrado, P.; de Miguel, I.; Lamberto, I.; Díez-Martínez, R.; Oyarzabal, J. Zebrafish: Speeding Up the Cancer Drug Discovery Process. Cancer Res. 2018, 78, 6048-6058. [CrossRef] [PubMed]

108. Evensen, L.; Johansen, P.L.; Koster, G.; Zhu, K.; Herfindal, L.; Speth, M.; Fenaroli, F.; Hildahl, J.; Bagherifam, S.; Tulotta, C.; et al. Zebrafish as a Model System for Characterization of Nanoparticles against Cancer. Nanoscale 2016, 8, 862-877. [CrossRef]

109. Franco, G.D.; Usai, A.; Funel, N.; Palmeri, M.; Montesanti, I.E.R.; Bianchini, M.; Gianardi, D.; Furbetta, N.; Guadagni, S.; Vasile, E.; et al. Use of Zebrafish Embryos as Avatar of Patients with Pancreatic Cancer: A New Xenotransplantation Model towards Personalized Medicine. World J. Gastroenterol. 2020, 26, 2792-2809. [CrossRef] [PubMed]

110. Jing, L.; Zon, L.I. Zebrafish as a Model for Normal and Malignant Hematopoiesis. Dis. Model. Mech. 2011, 4, 433-438. [CrossRef]

111. Lee, L.M.J.; Seftor, E.A.; Bonde, G.; Cornell, R.A.; Hendrix, M.J.C. The Fate of Human Malignant Melanoma Cells Transplanted into Zebrafish Embryos: Assessment of Migration and Cell Division in the Absence of Tumor Formation. Dev. Dyn. 2005, 233, 1560-1570. [CrossRef]

112. Lam, S.H.; Chua, H.L.; Gong, Z.; Lam, T.J.; Sin, Y.M. Development and Maturation of the Immune System in Zebrafish, Danio Rerio: A Gene Expression Profiling, in Situ Hybridization and Immunological Study. Dev. Comp. Immunol. 2004, 28, 9-28. [CrossRef]

113. Pontes, K.C.d.S.; Groenewoud, A.; Cao, J.; Ataide, L.M.S.; Snaar-Jagalska, E.; Jager, M.J. Evaluation of (Fli:GFP) Casper Zebrafish Embryos as a Model for Human Conjunctival Melanoma. Investig. Opthalmol. Vis. Sci. 2017, 58, 6065. [CrossRef] [PubMed]

114. Taylor, A.M.; Zon, L.I. Zebrafish Tumor Assays: The State of Transplantation. Zebrafish 2009, 6, 339-346. [CrossRef]

115. Haldi, M.; Ton, C.; Seng, W.L.; McGrath, P. Human Melanoma Cells Transplanted into Zebrafish Proliferate, Migrate, Produce Melanin, Form Masses and Stimulate Angiogenesis in Zebrafish. Angiogenesis 2006, 9, 139-151. [CrossRef]

116. He, S.; Lamers, G.E.; Beenakker, J.M.; Cui, C.; Ghotra, V.P.; Danen, E.H.; Meijer, A.H.; Spaink, H.P.; Snaar-Jagalska, B.E. Neutrophilmediated Experimental Metastasis Is Enhanced by VEGFR Inhibition in a Zebrafish Xenograft Model. J. Pathol. 2012, 227, 431-445. [CrossRef]

117. Pruvot, B.; Jacquel, A.; Droin, N.; Auberger, P.; Bouscary, D.; Tamburini, J.; Muller, M.; Fontenay, M.; Chluba, J.; Solary, E. Leukemic Cell Xenograft in Zebrafish Embryo for Investigating Drug Efficacy. Haematologica 2011, 96, 612-616. [CrossRef]

118. Zhao, H.; Tang, C.; Cui, K.; Ang, B.-T.; Wong, S.T.C. A Screening Platform for Glioma Growth and Invasion Using Bioluminescence Imaging: Laboratory Investigation. J. Neurosurg. 2009, 111, 238-246. [CrossRef]

119. Harfouche, R.; Basu, S.; Soni, S.; Hentschel, D.M.; Mashelkar, R.A.; Sengupta, S. Nanoparticle-Mediated Targeting of Phosphatidylinositol-3-Kinase Signaling Inhibits Angiogenesis. Angiogenesis 2009, 12, 325-338. [CrossRef]

120. Veinotte, C.J.; Dellaire, G.; Berman, J.N. Hooking the Big One: The Potential of Zebrafish Xenotransplantation to Reform Cancer Drug Screening in the Genomic Era. Dis. Model. Mech. 2014, 7, 745-754. [CrossRef]

121. Cabezas-Sainz, P.; Guerra-Varela, J.; Carreira, M.J.; Mariscal, J.; Roel, M.; Rubiolo, J.A.; Sciara, A.A.; Abal, M.; Botana, L.M.; López, R.; et al. Improving Zebrafish Embryo Xenotransplantation Conditions by Increasing Incubation Temperature and Establishing a Proliferation Index with ZFtool. BMC Cancer 2018, 18, 3. [CrossRef] [PubMed]

122. Vittori, M.; Motaln, H.; Turnšek, T.L. The Study of Glioma by Xenotransplantation in Zebrafish Early Life Stages. J. Histochem. Cytochem. 2015, 63, 749-761. [CrossRef] [PubMed]

123. Hill, A.J.; Teraoka, H.; Heideman, W.; Peterson, R.E. Zebrafish as a Model Vertebrate for Investigating Chemical Toxicity. Toxicol. Sci. 2005, 86, 6-19. [CrossRef] [PubMed]

124. Vu, M.N.; Kelly, H.G.; Wheatley, A.K.; Peng, S.; Pilkington, E.H.; Veldhuis, N.A.; Davis, T.P.; Kent, S.J.; Truong, N.P. Cellular Interactions of Liposomes and PISA Nanoparticles during Human Blood Flow in a Microvascular Network. Small 2020, 16, 2002861. [CrossRef]

125. Brown, H.K.; Schiavone, K.; Tazzyman, S.; Heymann, D.; Chico, T.J. Zebrafish Xenograft Models of Cancer and Metastasis for Drug Discovery. Expert Opin. Drug Discov. 2017, 12, 379-389. [CrossRef]

126. Long, Y.; Li, L.; Li, Q.; He, X.; Cui, Z. Transcriptomic Characterization of Temperature Stress Responses in Larval Zebrafish. PLoS ONE 2012, 7, e37209. [CrossRef]

127. Hu, Y.-L.; Qi, W.; Han, F.; Shao, J.Z.; Gao, J.Q. Toxicity Evaluation of Biodegradable Chitosan Nanoparticles Using a Zebrafish Embryo Model. Int. J. Nanomed. 2011, 6, 3351. [CrossRef]

128. Ghotra, V.P.S.; He, S.; de Bont, H.; van der Ent, W.; Spaink, H.P.; van de Water, B.; Snaar-Jagalska, B.E.; Danen, E.H.J. Automated Whole Animal Bio-Imaging Assay for Human Cancer Dissemination. PLoS ONE 2012, 7, e31281. [CrossRef] [PubMed]

129. van Pomeren, M.; Brun, N.R.; Peijnenburg, W.J.G.M.; Vijver, M.G. Exploring Uptake and Biodistribution of Polystyrene (Nano)Particles in Zebrafish Embryos at Different Developmental Stages. Aquat. Toxicol. 2017, 190, 40-45. [CrossRef] [PubMed]

130. Teijeiro-Valiño, C.; Yebra-Pimentel, E.; Guerra-Varela, J.; Csaba, N.; Alonso, M.J.; Sánchez, L. Assessment of the Permeability and Toxicity of Polymeric Nanocapsules Using the Zebrafish Model. Nanomedicine 2017, 12, 2069-2082. [CrossRef] 
131. Dal, N.K.; Kocere, A.; Wohlmann, J.; Van Herck, S.; Bauer, T.A.; Resseguier, J.; Bagherifam, S.; Hyldmo, H.; Barz, M.; De Geest, B.G.; et al. Zebrafish Embryos Allow Prediction of Nanoparticle Circulation Times in Mice and Facilitate Quantification of Nanoparticle-Cell Interactions. Small 2020, 16, 1906719. [CrossRef]

132. Baboci, L.; Capolla, S.; Di Cintio, F.; Colombo, F.; Mauro, P.; Dal Bo, M.; Argenziano, M.; Cavalli, R.; Toffoli, G.; Macor, P. The Dual Role of the Liver in Nanomedicine as an Actor in the Elimination of Nanostructures or a Therapeutic Target. J. Oncol. 2020, 2020, 1-15. [CrossRef]

133. Hayashi, Y.; Takamiya, M.; Jensen, P.B.; Ojea-Jiménez, I.; Claude, H.; Antony, C.; Kjaer-Sorensen, K.; Grabher, C.; Boesen, T.; Gilliland, D.; et al. Differential Nanoparticle Sequestration by Macrophages and Scavenger Endothelial Cells Visualized in Vivo in Real-Time and at Ultrastructural Resolution. ACS Nano 2020, 14, 1665-1681. [CrossRef]

134. Lieschke, G.J.; Currie, P.D. Animal Models of Human Disease: Zebrafish Swim into View. Nat. Rev. Genet. $2007,8,353-367$. [CrossRef]

135. Renshaw, S.A.; Loynes, C.A.; Trushell, D.M.I.; Elworthy, S.; Ingham, P.W.; Whyte, M.K.B. A Transgenic Zebrafish Model of Neutrophilic Inflammation. Blood 2006, 108, 3976-3978. [CrossRef] [PubMed]

136. Reitman, M.L. Of Mice and Men-Environmental Temperature, Body Temperature, and Treatment of Obesity. FEBS Lett. 2018, 592, 2098-2107. [CrossRef] [PubMed]

137. Kelly, A.; Hurlstone, A.F. The Use of RNAi Technologies for Gene Knockdown in Zebrafish. Brief. Funct. Genom. 2011, 10, 189-196. [CrossRef] [PubMed]

138. Slijkerman, R.; van Diepen, H.; Albert, S.; Dona, M.; Venselaar, H.; Zang, J.; Neuhauss, S.; Peters, T.; Broekman, S.; Pennings, R.; et al. Antisense Oligonucleotide-Based Treatment of Retinitis Pigmentosa Caused by Mutations in USH2A Exon 13. Genetics 2020, 28. [CrossRef]

139. Yang, T.; Fogarty, B.; LaForge, B.; Aziz, S.; Pham, T.; Lai, L.; Bai, S. Delivery of Small Interfering RNA to Inhibit Vascular Endothelial Growth Factor in Zebrafish Using Natural Brain Endothelia Cell-Secreted Exosome Nanovesicles for the Treatment of Brain Cancer. AAPS J. 2017, 19, 475-486. [CrossRef] 